\title{
Comparing Rates of Rock Weathering and Soil Formation between Two Temperate Forest Watersheds Differing in Parent Rock and Vegetation Type
}

\author{
Susumu S. ABE ${ }^{1 *}$, Takahiro HARADA ${ }^{1}$, Hiroshi OKUMURA ${ }^{1}$ and \\ Toshiyuki WAKATSUKI ${ }^{1,2}$ \\ ${ }^{1}$ Faculty of Agriculture, Kindai University (Nara, Nara 631-8505, Japan) \\ ${ }^{2}$ Emeritus Professor, Shimane University (Matsue, Shimane 690-8504, Japan)
}

\begin{abstract}
In the present study, the multiple regression analysis of mass balance equations of seven major geochemical elements ( $\mathrm{Al}, \mathrm{Fe}, \mathrm{Ca}, \mathrm{Mg}, \mathrm{K}, \mathrm{Na}, \mathrm{Si})$, among rock, soil, stream water, and precipitation in a watershed was used to simultaneously estimate the rates of rock weathering $(R W R)$ and soil formation $(S F R)$ in two template forest watersheds of Central Japan that had different types of vegetation and bedrock. Our results revealed that Mt. Kasuga watershed (MKW) with a primary evergreen broadleaf forest and gneissic bedrock had lower $R W R\left(1.51 \mathrm{t} \mathrm{ha}^{-1} \mathrm{yr}^{-1}\right)$ and SFR $\left(1.37 \mathrm{tha}^{-1}\right.$ $\mathrm{yr}^{-1}$ ) than those in Yata Hill watershed (YHW) with a semi-deciduous mixed forest and granitic bedrock $\left(R W R=1.83 \mathrm{tha}^{-1} \mathrm{yr}^{-1} ; S F R=1.79 \mathrm{t} \mathrm{ha}^{-1} \mathrm{yr}^{-1}\right)$. Based on the hypothesis that the vegetation effect on the watershed scale mass balance is negligible in a steady state ecosystem, we concluded that the bedrock type can be a main factor causing the difference in $R W R$ and $S F R$, as gneiss in MKW had smaller amounts of mica and feldspars and is supposed to have the higher resistance than granite in YHW to chemical weathering.
\end{abstract}

Disciplines: Soils, Fertilizers and plant nutrition

Additional key words: geochemical mass balance, multiple regression analysis, watershed management

\section{Introduction}

Rock weathering and soil formation are two important processes in geochemical cycles on terrestrial ecosystems. These processes take place on the earth's surface under various environmental conditions. In a humid temperate region, chemical weathering often predominates in the soil forming process, which regulates primary productivity of ecosystems through provision of mineral nutrients to various organisms that constitute the ecosystems (Likens 2004, Fahey et al. 2005), supports buffering capacity of acid deposits on a regional scale, and influences water chemistry in the ocean and atmospheric $\mathrm{CO}_{2}$ concentration on a global scale (Berner 1997, Taylor et al. 2012).

Reasonable estimation of the rock weathering rate $(R W R)$ as well as the soil formation rate (SFR) helps in better understanding geochemical processes on the earth's surface and sustainable management of the ecosystems, watersheds, and landscapes (Wakatsuki \&
Rasyidin, 1992). For example, estimation on $R W R$ allows for evaluation of the sequestration rate of atmospheric $\mathrm{CO}_{2}$ through chemical weathering; its promotion can be an important strategy in global warming mitigation (Hartmann et al. 2013, Song et al. 2013). In the meantime, the estimation of SFR enables evaluation of the sustainability of soil resource and ecosystem health as a counter measure of rate of soil erosion (Wakatsuki \& Rasyidin 1992): it is hypothesized that an ecosystem at a steady state should have a dynamic balance between soil formation and erosion (Montgomery 2007). Based on this hypothesis, we can say that highly weathered, strongly leached, decrepit soils such as Oxisols and Ultisols in tropical humid regions may eventually form if $S F R$ is far greater than the rate of soil erosion, whereas soil degradation and juvenile soils such as Regosols and Entisols may form as a result of land degradation and desertification if soil erosion is not compensated by soil formation, as is widely seen in many agricultural lands in the world (Montgomery 2007). Although numerous data 
on rates of soil erosion have been collected around the world, the data so far available on SFR are minimal. This scanty information on $S F R$ results mainly from limitations in the methodology of measuring $S F R$.

It is generally believed that the soil forming process requires decades to hundreds of years to produce a centimeter-thick layer of soil (Buol et al. 2003); herein SFR varies in response to the nature of parent rock, climate, topography, and organisms (Brady \& Weil 2007). In particular, the variability of pedogenesis may take place as a result of different rock disintegration and decay under different climatic zones (Pope et al. 1995). As stated above, reliable estimation of SFR displays certain needs but has been a bothersome challenge for soil researchers and geoscientists (Wakatsuki \& Rasyidin 1992). Meanwhile, reasonable estimation of $R W R$ has achieved some success thanks to catchment experiments, isotopic technique, and rare earth or trace element geochemistry (Velbel \& Price 2007). As a result, there has been much less effort to estimate $S F R$ than $R W R$.

The geochemical mass balance approach is a practical measure to estimate weathering rates of rocks and/or minerals on a watershed scale (White \& Blum 1995, Velbel \& Price 2007, Yang et al. 2013). This approach can also be applicable to estimate SFR (Alexander 1985, Wakatsuki \& Rasyidin 1992, Wakatsuki et al. 1993, Rasyidin \& Wakatsuki 1994, Huang et al. 2013), although far fewer studies have been conducted to estimate $S F R$ than to estimate $R W R$ (Huang et al. 2013). Wakatsuki et al. (1993) innovated an alternative method that allows for simultaneous estimation of the most probable mean values of $R W R$ and $S F R$, using multiple regression analysis of geochemical mass balance equations. Their method resulted in better predictions of RWR and SFR than did simple linear regression analysis (Wakatsuki et al. 1993). Appling this method, however, $R W R$ and $S F R$ have been assessed only for several locations: Iu River watershed (Japan) (Wakatsuki et al. 1993); Mt. Gadut (Indonesia); and Hubbardbrook (USA) (Rasyidin \& Wakatsuki 1994); and Fengxingzhuang (China) (Huang et al. 2013). In other words, the method developed in the study by Wakatsuki et al. (1993) has to date not been fully tested to evaluate its theoretical validation and practical applicability. To tackle this limitation, more tests are needed through its application on a variety of watersheds that show different environmental conditions.

Therefore, the aims of the present study were duplicate: (i) to estimate $R W R$ and $S F R$ in two neighboring forest watersheds of Central Japan which differ in vegetation and bedrock types using multiple regression analysis of geochemical mass balance equations as proposed in the study by Wakatsuki et al. (1993); and (ii) to comparatively examine the estimated $R W R$ and $S F R$ between these two watersheds each other so as to help understanding factors affecting these two variables.

\section{Materials and methods}

The study area lies in Nara, an old capital of Japan back to the $8^{\text {th }}$ century (710-794 A.D.) (Fig. 1). This area is situated under a humid temperate climate, classified into $C f a$ in the Köppen-Geiger classification system, having a mean annual precipitation of about $1,300 \mathrm{~mm}$ and a mean air temperature of $15^{\circ} \mathrm{C}$ for the past 30 years (Japan Meteorological Agency 2014).

\section{Site description}

Two types of headwater watersheds were selected for this study: one in Mt. Kasuga (peak=497 m); and the other in Yata Hill (peak $=315 \mathrm{~m}$ ), which hereafter are referred to as MKW and YHW, respectively (see Fig. 1). The distance between these two watersheds is approximately $12 \mathrm{~km}$. The vegetation type at MKW is a primary evergreen broadleaf forest consisting predominantly of Castanopsis cuspidate, Quercus salicina, Q. acuta, Q. sessilifolia, and Q. glauca (Shimoda et al. 1994, Maesako et al. 2007). On the other hand, YHW is covered by a secondary semi-deciduous forest, a mixed stand of deciduous broadleaf trees, e.g., Q. serrata, Q. acutissima, and Clethra barbinervis, and coniferous trees, e.g., Cryptomeria japonica and Chamaecyparis obtusa (Tabata et al. 2016, 2017). This vegetation type is often referred to as Satoyama forest in Japan, which indicates a semi-natural forest or a wooded hill nearby a village or residence (Takeuchi et al. 2002). Soils at MKW originate from granitic gneiss, while those at YHW formed on coarse-grained granite. Both parent rocks formed in the Cretaceous Era. These soils are generally classified into Brown Forest Soils in the Japan Forest Soil Classification System (Forest Soil Division 1976) or Udepts, i.e., Inceptisols with udic moisture regimes in the U.S. Soil Taxonomy (Soil Survey Staff 2006) (Table 1).

\section{Field sampling and monitoring}

Field sampling of rainfall and stream water was made for the period December 2010 to November 2011, while soil and rock samples were collected from 2008 to 2012. Weather information from a nearby weather station in the study area was obtained (Nara Local Meteorological Observatory: $\left.\quad 34^{\circ} 41.6^{\prime} \mathrm{N}, \quad 135^{\circ} 49.6^{\prime} \mathrm{E}\right)$, except for evapotranspiration which was estimated according to the study by Kondo et al. (1992). Total annual precipitation was approximately $1,500 \mathrm{~mm}$, while total annual 
evapotranspiration was about $760 \mathrm{~mm}$. Monthly rainfall surpassed its transpiration throughout the study period, except for January and August 2011 (Fig. 2).

Stream water samples were collected at an outlet port of each watershed when stream flow remained a base flow. Sampling frequency of stream water was once or twice a month depending on rainfall frequency. Stream discharge was calculated based on the rainfall, estimated evapotranspiration, and catchment area. These methodologies were applied following those of the previous works (Wakatsuki \& Rasyidin 1992, Wakatsuki et al. 1993, Rasyidin \& Wakatsuki 1994). In this
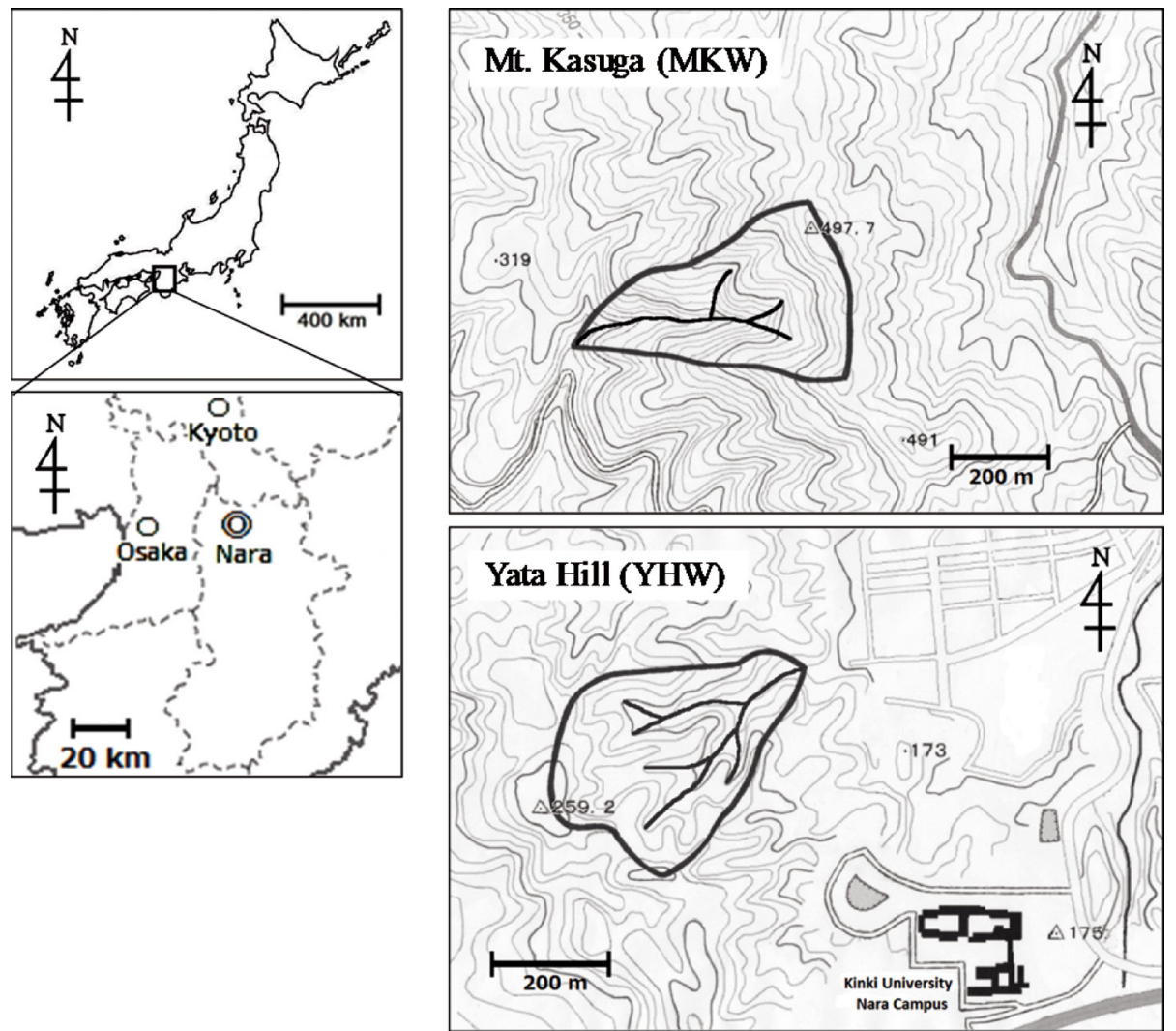

Fig. 1. Locations of the study sites

Table 1. General description of the studied watersheds

\begin{tabular}{lcc}
\hline \hline Site name & Mt. Kasuga (MKW) & Yata Hill (YHW) \\
\hline Latitude & $34^{\circ} 40^{\prime} \mathrm{N}$ & $34^{\circ} 40^{\prime} \mathrm{N}$ \\
Longitude & $135^{\circ} 51^{\prime} \mathrm{E}$ & $135^{\circ} 43^{\prime} \mathrm{E}$ \\
Summit altitude (m a.s.l) & 498 & 275 \\
Catchment area (ha) & 12.7 & 11.4 \\
Discharge $\left(\mathrm{m}^{3} \mathrm{ha}^{-1} \mathrm{yr}^{-1}\right)$ & 7885 & 8045 \\
Vegetation type & Evergreen broadleaf forest & Semi-deciduous broadleaf forest \\
Dominant tree species & Castanopsis cuspidate & Quercus serrata \\
& Quercus salicina & Quercus acutissima \\
& Quercus acuta & Clethra barvinervis \\
Quercus sessilifolia & Chamaecyparis obtusa \\
Bedrock geology & Quercus glauca & Cryptomeria japonica \\
Soil type & Cretaceous gneissic rocks & Cretaceous granitic rocks \\
Soil classification & Brown forest soils & Brown forest soils \\
\hline
\end{tabular}


calculation, the difference in vegetation type was not considered because Komatsu et al. (2011) in their study reported that there was no significant difference in evapotranspiration and runoff (interception ratio) between the broadleaf evergreen forests and the broadleaf partially deciduous forests in Japan, which correspond to the forest type in MKW and YHW, respectively. Rainfall samples were taken every month at the Kindai University's Nara Campus nearby YHW for the period December 2010 to November 2011, the same period as the sampling of the stream water.

Soil samples were taken along transect lines that were drawn to cover the major toposequences within each watershed studied, and at each sampling position soil samples were collected from genetic horizons up to 1 $\mathrm{m}$ in depth (MKW: $n=42$ from 10 profiles; YHW: $n=$ 107 from 26 profiles). Rock samples were collected from freshly exposed bedrock outcrops along the main stream at each watershed (MKW: $n=20$; YHW: $n=5$ ).

\section{Laboratory analysis and exploratory statistics}

Subsamples of the water samples were subjected to $\mathrm{pH}$ measurement using a $\mathrm{pH}$ meter with a glass electrode (D-54, Horiba Ltd., Tokyo) and the remaining samples were filtered with a membrane filter (Advantec No. 6, Toyo Roshi Kaisha Ltd., Tokyo) using a suction defecator. The filtrates were stored at $4{ }^{\circ} \mathrm{C}$ in a refrigerator and were analyzed chemically within a month.

Rock and soil samples were air-dried, ball-milled to fine powder, and stored in plastic bags at room temperature until the analysis. The rock powder was subjected to the x-ray diffraction analysis, after being loaded into an aluminum holder by a routine back-filling method (Amonette \& Zelazny 1994). The x-ray diffractograms were recorded by a Geiger flex counter (Miniflex II, Rigaku, Co., Tokyo) with Co-filtered $\mathrm{CuK} \alpha$ radiation $(40 \mathrm{~V}, 15 \mathrm{~A})$, under the routine measurement conditions: scanning interval of $0.2^{\circ} 2 \theta$ and scanning

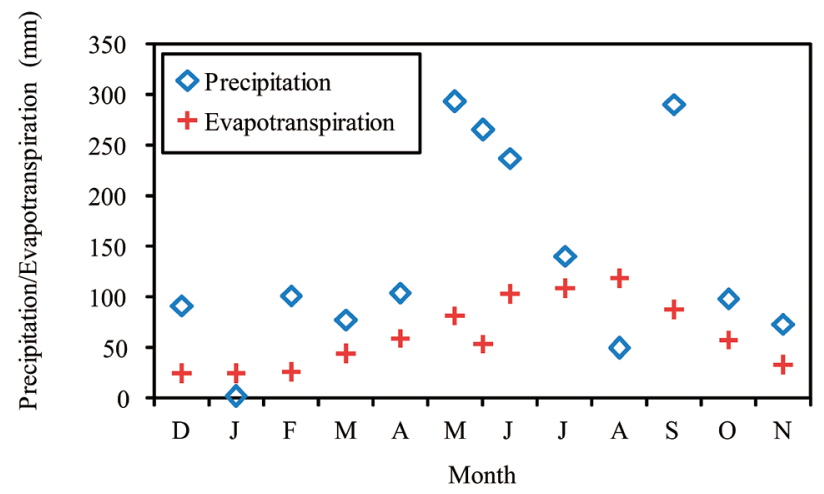

Fig. 2. Rainfall and evapotranspiration at the study area (December 2010-November 2012) speed of $2^{\circ} \min ^{-1}$ at $20^{\circ} \mathrm{C}$.

The rock powder was digested with hydrofluoric acid (HF) and hydrochloric acid ( $\mathrm{HCl})$ in a closed Teflon vessel under a microwave system (MWS-2, Berghof Co., Eningen, Germany). The soil powder was also digested under the same microwave system as the rock powder after decomposition of organic matter at $500^{\circ} \mathrm{C}$ in a muffle furnace and addition of nitric acid, hydrogen peroxide, $\mathrm{HF}$, and $\mathrm{HCl}$. The major geochemical elements soluble in the filtrates and digests were determined using Zeeman polarized atomic absorption spectrophotometry (Z-2300, Hitachi Ltd., Tokyo) after the addition of boric acid. Herein, aluminum (Al) and silicon (Si) were determined using a high-temperature flame under a constant flow of acetylene/nitrous oxide mixture gas, while calcium $(\mathrm{Ca})$, magnesium $(\mathrm{Mg})$, potassium $(\mathrm{K})$, iron $(\mathrm{Fe})$, and sodium $(\mathrm{Na})$ were measured with a lowtemperature flame under a controlled acetylene gas flow.

In the exploratory statistics, Student's $t$-test was applied to detect significant differences $(P<0.05)$ in elemental concentration in water, soil, and rock samples between MKW and YHW.

\section{Geochemical mass balance equations and multiple regression analysis}

Regarding the estimation of $R W R\left(\mathrm{t} \mathrm{ha}^{-1} \mathrm{yr}^{-1}\right)$ and $S F R\left(\mathrm{tha}^{-1} \mathrm{yr}^{-1}\right)$, geochemical mass balance in a watershed can be mathematized as the following equation (Wakatsuki et al. 1993):

$$
\begin{aligned}
& P \times P \mathrm{i}+R W R \times R W R \mathrm{i} \\
& =S F R \times S F R \mathrm{i}+D \times D \mathrm{i}+G \times G \mathrm{i}+V \times V \mathrm{i}
\end{aligned}
$$

where $P, D, R W R, S F R, G$, and $V$ denote amount of rainfall, river discharge, rock weathering rate $\left(\mathrm{t} \mathrm{ha}^{-1} \mathrm{yr}^{-1}\right)$, soil formation rate $\left(\mathrm{t} \mathrm{ha}^{-1} \mathrm{yr}^{-1}\right)$, ground water discharge $\left(\times 10^{4} \mathrm{~m}^{3} \mathrm{ha}^{-1} \mathrm{yr}^{-1}\right)$, and net growth of vegetation $\left(\mathrm{t} \mathrm{ha}^{-1}\right.$ $\left.\mathrm{yr}^{-1}\right)$, respectively; $P \mathrm{i}, D \mathrm{i}, G \mathrm{i}, R W R \mathrm{i}, S F R \mathrm{i}$, and $V \mathrm{i}$ indicate mean concentrations of the element $i$, any one of the seven major elements involved in geochemical cycling, i.e., $\mathrm{Al}, \mathrm{Ca}, \mathrm{Mg}, \mathrm{K}, \mathrm{Fe}, \mathrm{Na}$, and $\mathrm{Si}$, in rainfall, river, ground water $\left(\mathrm{g} \mathrm{m}^{-3}\right)$, rock, soil, and vegetation $\left(\times 10^{-4} \mathrm{~g}\right.$ $\left.\mathrm{t}^{-1}\right)$, respectively. Here $V$ and $G$ are considered negligible if the assessment is made in a mountainous watershed covered by a steady state vegetation (Wakatsuki et al. 1992), because groundwater loss is unlikely in mountainous areas overlying impermeable bedrock, and nutrient uptake by the growth of new vegetation can be balanced by nutrients released from decay of old vegetation in steady state ecosystems (Huang et al. 2013). Therefore, equation (1) can be transformed to another equation as follows: 


$$
R W R \times R W R_{\mathrm{i}}-S F R \times S F R_{\mathrm{i}}=D \times D_{\mathrm{i}}-P \times P_{\mathrm{i}}
$$

Applying equation (2) to each of the given seven elements, 21 sets of $R W R$ and $S F R$ were obtained at the end. Subsequently, the most probable values of $R W R$ and $S F R$ were calculated as partial regression coefficients of $R W R \mathrm{i}$ and SFRi, respectively. Here, RWRi and SFR i were determined to minimize residual sum of squares, while putting the right-side members $\left(D \times D_{\mathrm{i}}-P \times P_{\mathrm{i}}\right)$ in the equation (2) as dependent variables in relation to the independent variables $R W R_{\mathrm{i}}$ and $S F R_{\mathrm{i}}$ without constant terms. As a result, $R W R$ and $S F R$ represent the average rate of rock weathering and soil formation on a watershed basis, respectively. The multiple regression shows the better prediction as compared with the simple linear regression (Wakatsuki et al. 1993).

All statistical analyses made in this study were performed using the statistical software SPSS 17 (ver. 17.0.0, SPSS Inc., Chicago, Illinois).

\section{Results}

\section{Rock mineralogy}

The X-ray diffraction analysis revealed that the rock sample from MKW mainly consisted of quartz in addition to small amounts of feldspars and mica, while the rock sample from YHW was comprised of quartz along with relatively large amounts of feldspars and mica (Fig. 3).

\section{Rainfall and stream water chemistry}

Changes in chemistry of rainwater in the study region and in the stream water in the studied watersheds are shown in Figure 4 and Figure 5, respectively. The rainwater showed a mildly acidic reaction (4.4-5.9; $N=$ $14)$, while the stream water had a slightly acidic to mildly alkaline reaction (MKW: 6.7-8.2, $N=12$; YHW: 6.2-7.2, $N=12$ ) in both watersheds throughout the study period. There was a significant difference in the mean $\mathrm{pH}$ value

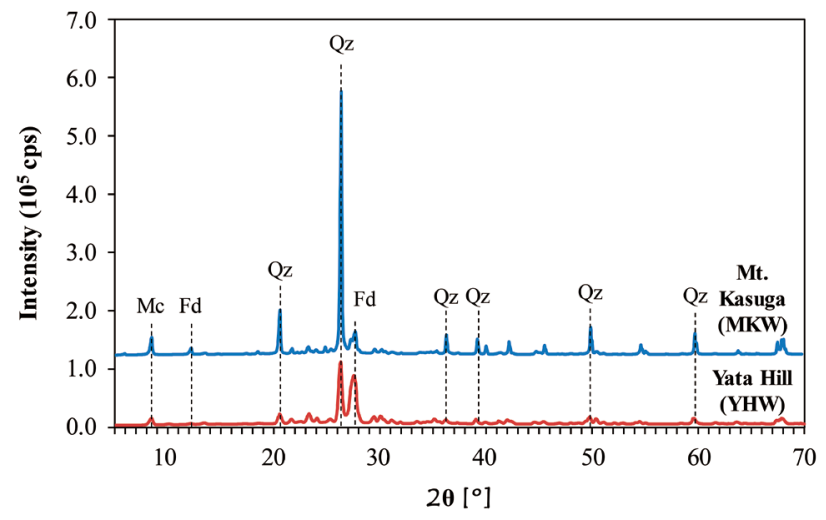

Fig. 3. X-ray diffraction diagrams of the rock samples collected from the studied watersheds of the rainwater in the study region $(5.2 \pm 0.4)$ as compared with the $\mathrm{pH}$ values of the stream water in both watersheds investigated in this study (MKW: $7.2 \pm 0.5$; YHW: $6.9 \pm$ $0.3)$. Concentrations of the examined chemical elements in the rainwater were found to be very low (Fig. 4), while over the study period, those in the stream water were found to be higher than in the rainwater (Fig. 5). The highest concentration was found either of $\mathrm{Si}$ or $\mathrm{Na}$, followed in order by $\mathrm{Ca}, \mathrm{Mg}$, and $\mathrm{K}$, while $\mathrm{Fe}$ and $\mathrm{Al}$ were found in a very low concentration in both studied watersheds for most of the period of this study. Mean concentrations of the examined elements in the rainwater gave a significant difference from those in the stream water of the studied watersheds, except for $\mathrm{Al}$ and $\mathrm{Fe}$ in MKW. Comparing the stream water chemistry between the studied watersheds, $\mathrm{Al}, \mathrm{Ca}$, and Fe were significantly lower in MKW (Al: $0.05 \pm 0.04 \mathrm{mg} \mathrm{L}^{-1}$; Ca: $3.75 \pm 0.87$ $\mathrm{mg} \mathrm{L}^{-1}$; Fe: $0.05 \pm 0.03 \mathrm{mg} \mathrm{L}^{-1}$ ) than were those in YHW (Al: $0.16 \pm 0.12 \mathrm{mg} \mathrm{L}^{-1}$; Ca: $5.37 \pm 1.25 \mathrm{mg} \mathrm{L}^{-1}$; Fe: $0.15 \pm$ $0.09 \mathrm{mg} \mathrm{L}^{-1}$ ). In contrast, during the study period mean concentrations of $\mathrm{Mg}$ and $\mathrm{K}$ in the stream water were significantly higher in MKW (Mg: $2.09 \pm 0.12 \mathrm{mg} \mathrm{L}^{-1}$; K: $2.23 \pm 0.37 \mathrm{mg} \mathrm{L}^{-1}$ ) than were mean concentrations of $\mathrm{Mg}$ and $\mathrm{K}$ in YHW (Mg: $1.14 \pm 0.09 \mathrm{mg} \mathrm{L}^{-1} ; \mathrm{K}: 1.83 \pm 0.37$ $\mathrm{mg} \mathrm{L}^{-1}$ ).

\section{Elemental composition of rocks and soils}

Chemical composition of the rock and soil samples collected from the studied watersheds is given in Figure 6 and Figure 7, respectively. The rock samples from MKW

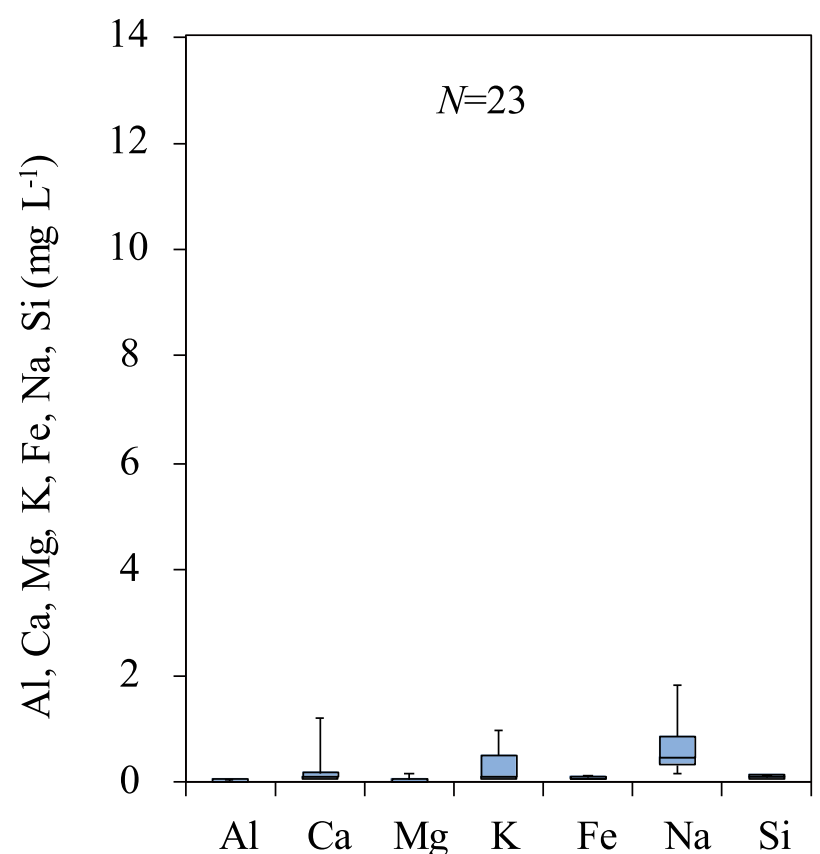

Fig. 4. Water chemistry in the rainwater samples collected in the study area $(n=23)$ 
showed a higher variability of elemental composition and had significantly lower contents of $\mathrm{Al}\left(68.2 \pm 21.3 \mathrm{~g} \mathrm{~kg}^{-1}\right)$, $\mathrm{Ca}\left(10.2 \pm 3.5 \mathrm{~g} \mathrm{~kg}^{-1}\right)$, and $\mathrm{Na}\left(17.4 \pm 7.0 \mathrm{~g} \mathrm{~kg}^{-1}\right)$ as compared with rock samples in YHW (Al: $93.0 \pm 4.9 \mathrm{~g}$ $\mathrm{kg}^{-1}$; Ca: $26.3 \pm 1.5 \mathrm{~g} \mathrm{~kg}^{-1}$; Na: $\left.23.9 \pm 1.0 \mathrm{~g} \mathrm{~kg}^{-1}\right)$. Yet, the other elements did not show any significant difference between these two watersheds.

Regarding soil elemental composition, MKW had significantly lower contents of $\mathrm{Al}\left(83.5 \pm 17.1 \mathrm{~g} \mathrm{~kg}^{-1}\right), \mathrm{Ca}$ $\left(3.1 \pm 1.0 \mathrm{~g} \mathrm{~kg}^{-1}\right)$, and $\mathrm{Mg}\left(3.6 \pm 1.2 \mathrm{~g} \mathrm{~kg}^{-1}\right)$ but larger amounts of $\mathrm{Na}\left(5.7 \pm 5.2 \mathrm{~g} \mathrm{~kg}^{-1}\right)$ and $\mathrm{Si}\left(300 \pm 30.7 \mathrm{~g} \mathrm{~kg}^{-1}\right)$ than did YHW (Al, $98.0 \pm 9.2 \mathrm{~g} \mathrm{~kg}^{-1}$; Ca, $13.5 \pm 4.9 \mathrm{~g} \mathrm{~kg}^{-1}$; $\mathrm{Mg}, 4.4 \pm 1.3 \mathrm{~g} \mathrm{~kg}^{-1}$; Na, $13.7 \pm 4.1 \mathrm{~g} \mathrm{~kg}^{-1} ; \mathrm{Si}, 274 \pm 23.6 \mathrm{~g}$ $\mathrm{kg}^{-1}$ ). However, no significant difference was found in $\mathrm{K}$ and Fe between these two watersheds.

On the other hand, the rock samples had significantly higher contents of $\mathrm{Ca}, \mathrm{Mg}\left(6.4 \pm 5.1 \mathrm{~g} \mathrm{~kg}^{-1}\right), \mathrm{K}(29.3 \pm$ $\left.12.0 \mathrm{~g} \mathrm{~kg}^{-1}\right), \mathrm{Na}$ and $\mathrm{Si}\left(329 \pm 44.6 \mathrm{~g} \mathrm{~kg}^{-1}\right)$ but had significantly lower contents of $\mathrm{Al}$ and Fe $(18.7 \pm 12.7 \mathrm{~g}$ $\mathrm{kg}^{-1}$ ) than did the soil samples $\left(\mathrm{Fe}, 33.2 \pm 11.9 \mathrm{~g} \mathrm{~kg}^{-1}\right)$ in

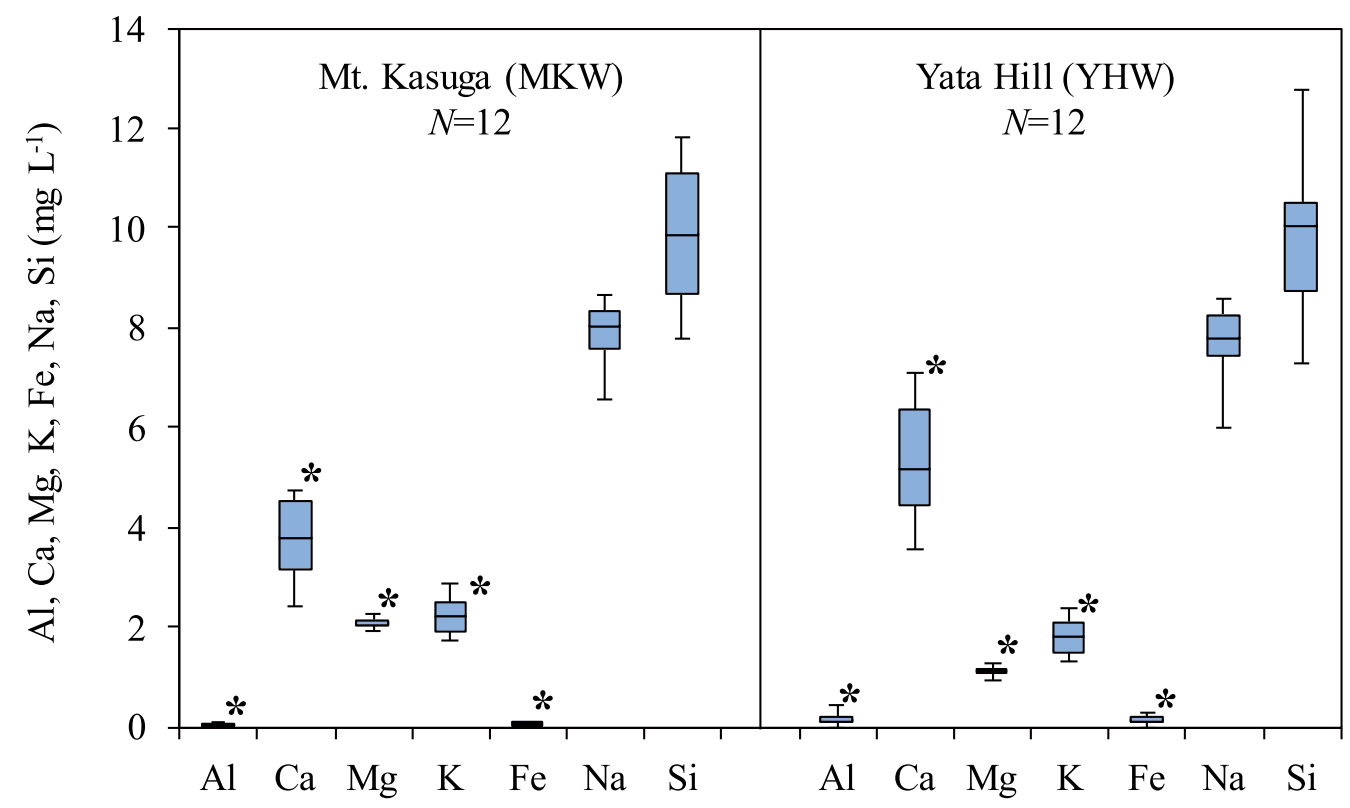

Fig. 5. Water chemistry in the stream water samples collected from the studied watersheds

(MKW: $n=12$; YHW: $n=12$ )

* indicates a significant difference $(P<0.05)$ in the mean concentration between the studied watersheds.

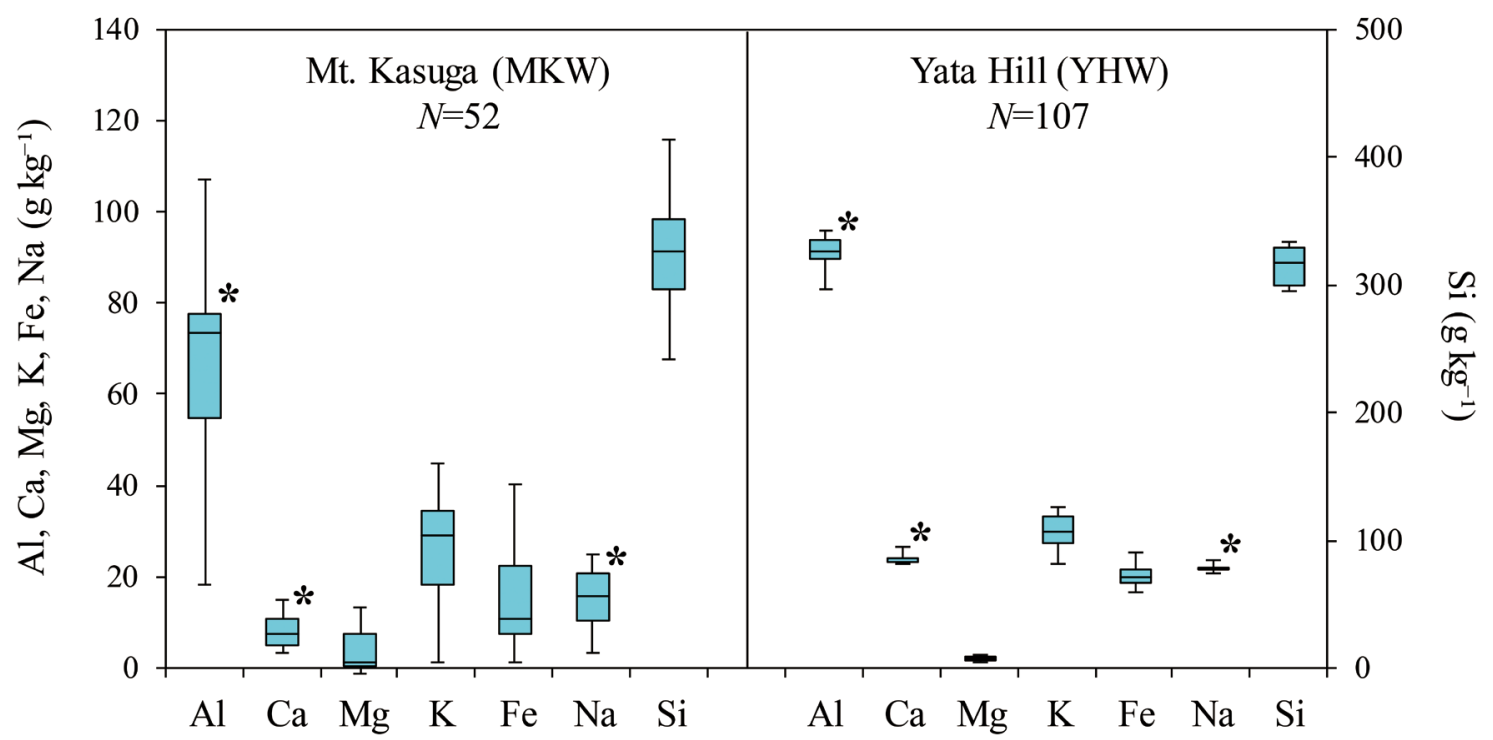

Fig. 6. Elemental composition of the rock samples collected from the studied watersheds

(MKW: $n=20$; YHW: $n=5$ )

* indicates a significant difference $(P<0.05)$ in the mean concentration between the studied watersheds. 
MKW. Similar results were obtained for YHW except for $\mathrm{Al}$ and $\mathrm{Mg}$ which didn't show any significant difference between the bedrock $\left(\mathrm{Mg}, 4.1 \pm 0.63 \mathrm{~g} \mathrm{~kg}^{-1}\right)$ and soil.

\section{Rates of rock weathering and soil formation}

Seven mass balance equations, each of which dealt with the respective element ( $\mathrm{Al}, \mathrm{Ca}, \mathrm{Mg}, \mathrm{K}, \mathrm{Fe}, \mathrm{Na}, \mathrm{Si}$ ), were prepared respectively for $\mathrm{MKW}$ and $\mathrm{YHW}$, according to equation (2) (Table 2). Based on these equations, multiple regression analysis (the method of least squares to determine undetermined coefficients) was applied to calculate $R W R$ and SFR simultaneously for each studied watershed, which revealed that MKW had lower values of $R W R$ and $S F R$ than those in YHW (Table 3). Furthermore, total amount of these seven elements exported $(T A E)$ from MKW and YHW were 0.18 and 0.19

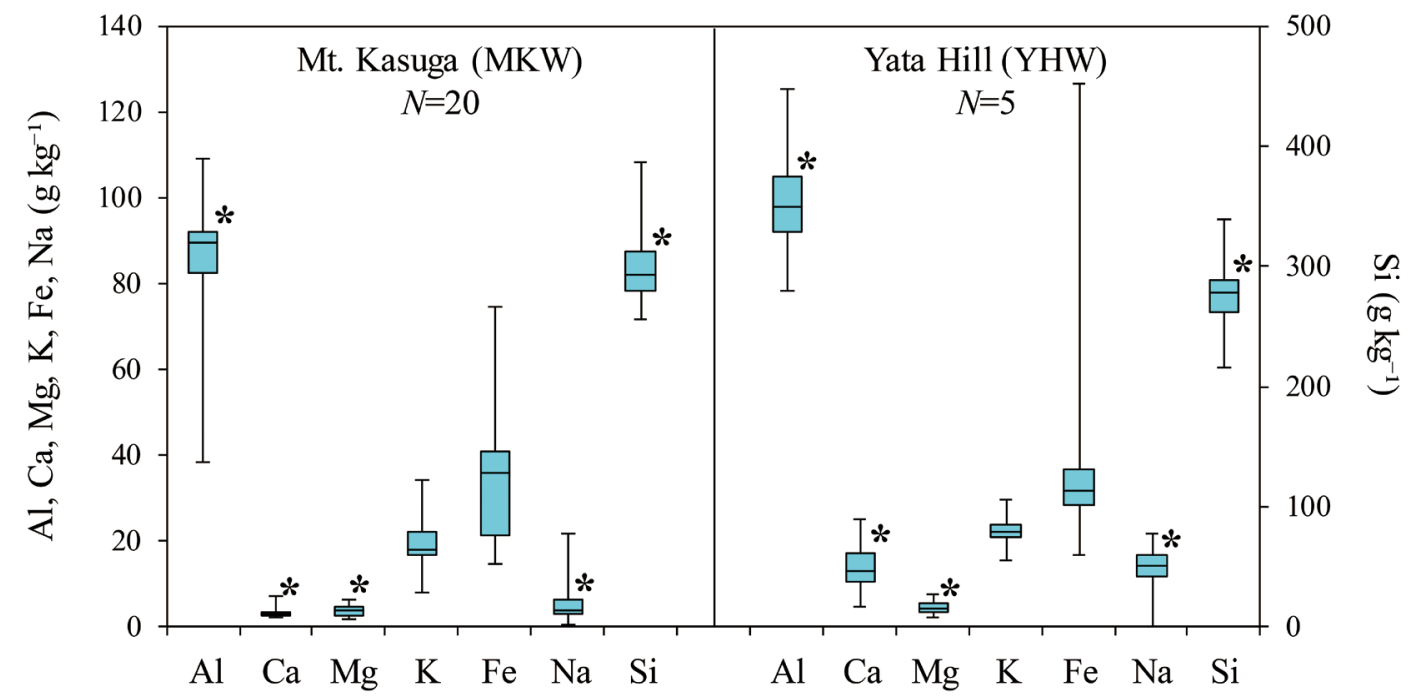

Fig. 7. Elemental composition of the soil samples collected from the studied watersheds (MKW: $n=42$; YHW: $n=107$ )

* indicates a significant difference $(P<0.05)$ in the mean concentration between the studied watersheds.

Table 2. Mass balance equations prepared for seven geochemical elements at each of the studied watersheds

\begin{tabular}{cc}
\hline \hline Element & Equation \\
\hline $\mathrm{Al}$ & Mt. Kasuga $(M K W)$ \\
$\mathrm{Ca}$ & $1.01 \times R W R-0.31 \times S F R=3.75 \times 0.79-0.19 \times 1.55$ \\
$\mathrm{Mg}$ & $0.64 \times R W R-0.36 \times S F R=2.09 \times 0.79-0.03 \times 1.55$ \\
$\mathrm{~K}$ & $2.93 \times R W R-2.01 \times S F R=2.23 \times 0.79-0.27 \times 1.55$ \\
$\mathrm{Fe}$ & $1.87 \times R W R-3.26 \times S F R=0.05 \times 0.79-0.06 \times 1.55$ \\
$\mathrm{Na}$ & $1.74 \times R W R-0.57 \times S F R=7.94 \times 0.79-0.62 \times 1.55$ \\
$\mathrm{Si}$ & $32.6 \times R W R-30.0 \times S F R=9.85 \times 0.79-0.11 \times 1.55$ \\
\hline $\mathrm{Al}$ & $9.30 \times R W R-9.80 \times S F R=0.16 \times 0.80-0.08 \times 1.57$ \\
$\mathrm{Ca}$ & $2.63 \times R W R-1.35 \times S F R=5.37 \times 0.80-0.19 \times 1.57$ \\
$\mathrm{Mg}$ & $0.41 \times R W R-0.43 \times S F R=1.14 \times 0.80-0.03 \times 1.57$ \\
$\mathrm{~K}$ & $3.19 \times R W R-2.21 \times S F R=1.83 \times 0.80-0.27 \times 1.57$ \\
$\mathrm{Fe}$ & $2.26 \times R W R-3.32 \times S F R=0.15 \times 0.80-0.06 \times 1.57$ \\
$\mathrm{Na}$ & $2.39 \times R W R-1.37 \times S F R=7.76 \times 0.80-0.62 \times 1.57$ \\
$\mathrm{Si}$ & $31.5 \times R W R-27.4 \times S F R=9.96 \times 0.80-0.11 \times 1.57$ \\
\hline
\end{tabular}

Mean values of the individual elements in rock, soil, precipitation, and stream were used to prepare these equations. 
$\mathrm{t} \mathrm{ha}^{-1} \mathrm{yr}^{-1}$, respectively. Herein, MKW worked as a net sink of $\mathrm{Al}$ and $\mathrm{Fe}$ with a mean of 0.79 and $0.50 \mathrm{~kg} \mathrm{ha}^{-1}$ $\mathrm{yr}^{-1}$, respectively, but a net source of $\mathrm{Ca}, \mathrm{Mg}, \mathrm{K}, \mathrm{Na}$, and Si with a mean of $26.7,16.1,13.4,53.0$, and $76.0 \mathrm{~kg} \mathrm{ha}^{-1}$ $\mathrm{yr}^{-1}$, respectively, whereas YHW became a net source of all the examined elements (mean: Al, 0.07; Ca, 40.3; Mg, 8.76; K, 10.6; Fe, 0.25; Na, 52.7; Si, $78.4 \mathrm{~kg} \mathrm{ha}^{-1} \mathrm{yr}^{-1}$ ).

\section{Discussion}

\section{Chemistry of water, rocks, and soils}

The stream water had a nearly neutral reaction in contrast to the rainwater, which showed an acidic reaction (pH: rainwater $=5.2 \pm 0.4$; MW stream water $=7.2 \pm 0.5$; YHW stream water $=6.9 \pm 0.3$ ). This result represents a geochemical neutralization function of the chemical weathering of rocks through the dissolution of the bases (Meybeck 1987, Peters et al. 2006, Velbel \& Price 2007) as indicated by the much higher concentrations of $\mathrm{Ca}$, $\mathrm{Mg}, \mathrm{K}$, and $\mathrm{Na}$ in the stream water than concentrations of $\mathrm{Ca}, \mathrm{Mg}, \mathrm{K}$, and $\mathrm{Na}$ in the rainwater (see Figs. 4 and 5). Also, dissolved $\mathrm{Si}$ was found in a considerable concentration (ca. $10 \mathrm{mg} \mathrm{L}^{-1}$ ) in the stream water in contrast to the rainwater (nearly nil). These elements, which are the major geochemical elements consisting of the rocks and minerals, dissolve during the chemical weathering (Sommer et al. 2006), run into the stream and river, and eventually accumulate in the ocean (DeMaster 1981, Hirata \& Muraoka 1988). It is known that stream water contains the weathering products of the rock (Wakatsuki \& Rasyidin 1992, Nédeltcheva, et al. 2006). Although Al was among the predominant elements found in both rocks and soils, it emerged in the stream water in a very low concentration, displaying a sharp contrast to the behavior of the base elements. Aluminum is very low in mobility during rock weathering and soil formation, resulting often in certain enrichment in the soil relative to the rock. In contrast, the bases were subject to the loss by leaching, especially in soils with acidic reactions, and were thus released to water bodies (Wakatsuki et al. 1993, Rasyidin \& Wakatsuki 1994, Likens 2004, Huang et al. 2013, Yang et al. 2013). As a consequence, Si, Al, and Fe remain preferentially in terrestrial land, in particular under aerobic environments, while the bases accumulate in the ocean in a global geochemical cycle (Wakatsuki 1985).

Table 3. Comparison of rates of rock weathering and soil formation between the watersheds with different environmental conditions

\begin{tabular}{|c|c|c|c|c|c|c|}
\hline Entry & $\begin{array}{l}\text { Mt. Kasuga } \\
(\mathrm{MKW})\end{array}$ & $\begin{array}{l}\text { Yata Hill } \\
\text { (YHW) }\end{array}$ & \multicolumn{3}{|c|}{ Iu River ${ }^{\mathrm{a}}$} & Fengxingzhuang ${ }^{\mathrm{b}}$ \\
\hline Air temperature $\left({ }^{\circ} \mathrm{C}\right)$ & \multirow{2}{*}{\multicolumn{2}{|c|}{$\begin{array}{r}\longrightarrow \\
\square \\
\square\end{array}$}} & \multirow{2}{*}{\multicolumn{3}{|c|}{$\begin{array}{r}\longrightarrow \\
\\
\end{array}$}} & 16.5 \\
\hline Precipitation $\left(\mathrm{mm}\right.$ year $\left.{ }^{-1}\right)$ & & & & & & 1585 \\
\hline Vegetation & $\begin{array}{c}\text { Evergreen } \\
\text { broadleaf forest }\end{array}$ & $\begin{array}{l}\text { Semi-deciduous } \\
\text { mixed forest }\end{array}$ & \multicolumn{3}{|c|}{ Semi-deciduous mixed forest } & Coniferous forest \\
\hline Parent rock & Gneiss & Granite & Pyroclast & Andesite & Granite & Granite \\
\hline Rock weathering rate $(R W R)\left(\mathrm{t} \mathrm{ha}^{-1} \mathrm{yr}^{-1}\right)$ & 1.51 & 1.83 & 4.60 & 2.20 & 0.85 & 1.04 \\
\hline Soil formation rate $(S F R)\left(\mathrm{t} \mathrm{ha}^{-1} \mathrm{yr}^{-1}\right)$ & 1.37 & 1.79 & 3.80 & 1.80 & 0.60 & 0.95 \\
\hline$R W R-S F R(R M S)\left(\mathrm{t} \mathrm{ha}^{-1} \mathrm{yr}^{-1}\right)$ & 0.14 & 0.04 & 0.80 & 0.40 & 0.25 & 0.09 \\
\hline Total elemental export $(T A E)\left(\mathrm{t} \mathrm{ha}^{-1} \mathrm{yr}^{-1}\right)$ & 0.18 & 0.19 & 0.40 & 0.46 & 0.23 & 0.10 \\
\hline$|R M S-T A E|\left(\mathrm{t} \mathrm{ha}^{-1} \mathrm{yr}^{-1}\right)$ & 0.04 & 0.15 & 0.40 & 0.06 & 0.02 & 0.01 \\
\hline \multicolumn{7}{|l|}{ Rock composition $\left(\mathrm{g} \mathrm{kg}^{-1}\right)$} \\
\hline Aluminum (Al) & $68.2(1.22)^{\mathrm{c}}$ & $93.0(1.05)$ & $81.7(1.08)$ & $74.6(1.29)$ & $71.0(1.54)$ & $67.2(1.21)$ \\
\hline Calcium (Ca) & $10.2(0.31)$ & $26.3(0.51)$ & $31.5(0.22)$ & N/A & $6.86(0.61)$ & $8.20(0.66)$ \\
\hline Magnesium (Mg) & $6.44(0.56)$ & $4.14(1.05)$ & $13.1(0.50)$ & $10.5(0.89)$ & $4.32(0.94)$ & $1.60(1.81)$ \\
\hline Potassium (K) & $29.3(0.68)$ & $31.9(0.69)$ & $37.8(0.65)$ & $27.7(0.31)$ & $43.1(1.10)$ & $37.0(1.00)$ \\
\hline Iron $(\mathrm{Fe})$ & $18.7(1.74)$ & $22.6(1.46)$ & $41.3(0.83)$ & $26.5(1.38)$ & $14.6(1.55)$ & N/A \\
\hline Sodium (Na) & $17.4(0.33)$ & $23.9(0.57)$ & $53.6(0.53)$ & $35.2(0.25)$ & $39.0(0.53)$ & $22.7(0.86)$ \\
\hline Silicon (Si) & $326(0.92)$ & $315(0.87)$ & $271(1.05)$ & $300(0.87)$ & $329(0.79)$ & $352(0.92)$ \\
\hline
\end{tabular}

a Rasyidin and Wakatsuki (1994)

${ }^{\mathrm{b}}$ Huang et al. (2013)

${ }^{\mathrm{c}}$ Numbers in parentheses indicate an enrichment/dilution factor in the individual element in the soil against the rock: $>1=$ enrichment, $<1=$ dilution 
On the other hand, there was a significantly higher concentration of $\mathrm{Al}$ and $\mathrm{Ca}$ in both stream water and soil in MKW as opposed to those concentrations of $\mathrm{Al}$ and $\mathrm{Ca}$ in YHW, reflecting the elements and minerals of which the bedrocks consisted. Indeed, the present data have revealed that the gneiss from MKW had a lower content of $\mathrm{Ca}$ and $\mathrm{Na}$ and contained smaller amounts of feldspars and mica than did the granite from YHW. Magnesium concentration, however, gave conflicting results: $\mathrm{Mg}$ concentration was significantly higher in the stream water and rock at $\mathrm{MKW}$ than was $\mathrm{Mg}$ concentration in steam and rock of YHW, although an opposite trend was found in the soil without any significant difference. This result suggests that $\mathrm{Mg}$ in granite is less insoluble as compared to $\mathrm{Mg}$ in gneiss during rock weathering and soil formation. The previous reports (Rasyidin \& Wakatsuki 1994, Huang et al. 2013) also documented similar trends of $\mathrm{Mg}$ behavior in granite-derived watersheds (Wakatsuki et al. 1993, Rasyidin \& Wakatsuki 1994). These results suggest that Mg-containing minerals such as mica in gneiss dissolve more rapidly than do those in granite during rock weathering.

\section{Rates of rock weathering and soil formation}

Based on theoretical hypotheses and prerequisite assumptions, any differences in $R W R$ and $S F R$ found between YHW and MKW should be attributed to either or both of bedrock type and vegetation one, because the other factors affecting $R W R$ and $S F R$, i.e., climate, relief, and soil age, are considered comparable between KMW and YHW. Indeed, considering the proximity (distance: $12 \mathrm{~km}$ ) and similarity in elevation (disparity of peak height: $182 \mathrm{~m}$ ) between these two watersheds, there would be little difference in air temperature, precipitation and input of proton, which have been identified by the previous studies as the major environmental factors affecting $R W R$ and $S F R$ (Wakatsuki et al. 1993, White \& Blum 1995, Huang et al. 2013). However, the results obtained in this study need careful interpretation because the differences in $R W R$ and $S F R$ between these two watersheds were not great (see Table 3 ), and they would be statistically not different to a significant extent, considering seasonal variations of $R W R(\mathrm{CV}=63 \%)$ and $S F R(\mathrm{CV}=73 \%)$ reported in the previous study (Huang et al. 2013).

From the viewpoint of rock durability against chemical weathering, gneiss as a metamorphic rock is considered more resistant to granite as the igneous rock granite is (Lindsey et al. 1982). It is generally accepted that metamorphic rock forms under higher temperature and pressure and has larger amount of mafic (or colored) minerals than does igneous rock (Brady \& Weil 2007). In fact, this observation supported by the results of the $\mathrm{X}$-ray diffraction analysis: gneiss from MKW contained a smaller amount of feldspars and micas, which are susceptible to the chemical weathering, than did granite from YHW (Fig. 4). This can be the main reason for the lower $R W R$ and $S F R$ in MKW than those in YHW.

On the other hand, the influence of vegetation on $R W R$ and $S F R$ remains elusive because of the prerequisite assumption: vegetation in both studied watersheds are in a steady state and thus nutrients taken by the growth of new vegetation are balanced by nutrients released from decay of old vegetation. This assumption has been set up in all the previous studies (Wakatsuki \& Rasyidin 1992, Wakatsuki et al. 1993, Rasyidin \& Wakatsuki 1994, Huang et al. 2013). However, there is enough evidence of the effect of vegetation on rock weathering: the vegetation augments export of geochemical elements from watersheds due to accelerated weathering of soil minerals (Moulton et al. 2000, Andrews et al. 2008). This conflict emphasizes the need of further research on the improvement of the methodology that was originally designed in the study by Wakatsuki et al. (1993). Regarding the vegetation effect on $R W R$ and $S F R$, it would be worth mentioning the difference between the value subtracting $S F R$ from $R W R$ (i.e., $R M S=R W R-$ $S F R)$ and total amount of exported elements (TAE). There was larger $R M S$ in YHW $\left(0.14 \mathrm{t} \mathrm{ha}^{-1} \mathrm{yr}^{-1}\right)$ than there was $R M S$ in MKW $\left(0.04 \mathrm{tha}^{-1} \mathrm{yr}^{-1}\right)$, in spite of little difference in $T A E$ between these two watersheds $(\mathrm{MKW}=0.18 \mathrm{t}$ $\mathrm{ha}^{-1} \mathrm{yr}^{-1}$; YHW $=0.19 \mathrm{t} \mathrm{ha}^{-1} \mathrm{yr}^{-1}$ ) (Table 3). Herein, the difference between $R M S$ and TAE exhibits an estimation error in either or both of $R W R$ and $S F R$ since it is theoretically nil if all hypotheses made in this study are valid (Wakatsuki \& Rasyidin 1992, Wakatsuki et al. 1993, Rasyidin \& Wakatsuki 1994). This estimation error may be attributed largely to the vegetation effect which has not been assessed in this study; neither has it been done in the previous studies (Wakatsuki \& Rasyidin 1992, Wakatsuki et al. 1993, Rasyidin \& Wakatsuki 1994, Huang et al. 2013). Although the vegetation in MKW has most likely been a steady state thanks to the protection from logging and hunting over the centuries, the one in YHW might be still in transition because it had been maintained under anthropogenic disturbance and exploitation (e.g., collection of fuel wood) until around 1970 (Tabata et al. 2016, 2017). The larger estimation error indicated by the larger difference between $R M S$ and $T A E$ in YHW than that in MKW might be derived from vegetation. However, this has not been demonstrated so far because of the methodological limitation.

Both $R W R$ and $S F R$ obtained in this study were considerably lower than obtained $R W R$ and $S F R$ of other 
watersheds overlying other types of bedrocks such as basic pyroclastic material and andesite in the Iu River watershed of Japan (Table 3) in spite of the fact that the climate and relief in the Iu River watershed are not much different from those in MKW and YHW (the latter has similar vegetation type too). Therefore, it is suggested that the lower $R W R$ and $S F R$ that are obtained in this study as compared with $R W R$ and $S F R$ obtained as reported by the previous study are also attributed largely to differences in parent material. Basic pyroclastic material and andesite in the Iu River watershed are categorized into basic and neutral rocks, respectively, having a larger amount of mafic minerals with relatively lower silica concentration, but a comparatively higher content of bases than acidic rock such as gneiss and granite in this study (Brady \& Weil 2007). The susceptibility of pyroclastic material and andesite to chemical weathering can be represented by the higher $T A E$ in the Iu River watershed than in watersheds in our study.

On the other hand, both $R W R$ and $S F R$ found in YHW of this study were higher than those of the Iu River watershed of Japan (granite bedrock site only) and of the Fengxingzhuang watershed of South China reported in previous studies (Rasyidin \& Wakatsuki 1994, Huang et al. 2013), despite all these watersheds having granitic bedrock under a humid temperate climate. Regardless of the same bedrock type, andesite in these watersheds gave certain variation in chemical composition and probably in mineral composition as well. For instance, granite in YHW had a higher content of $\mathrm{Al}$ and $\mathrm{Ca}$, but a smaller amount of $\mathrm{Na}$ and $\mathrm{Si}$ than did that in the Iu River watershed. Such variation in chemical and mineralogical composition among granitic rocks is a possible cause of variation in $R W R$ and $S F R$ in the given granitic watersheds. Although YHW and the Iu River watershed showed almost the same TAE one another, TAE in YHW and the Iu River watershed was considerably higher than the Fengxingzhuang watershed. In this regard, however, we may also need to consider other environmental factors in addition to the parent material such as air temperature, rainfall, and proton $\left(\mathrm{H}^{+}\right)$input through acid deposition (Huang et al. 2013), especially when comparing geographically different watersheds.

\section{Acknowledgments}

The present study was financially supported by the Japan Society for the Promotion of Science (Kakenhi for the Young Scientist No.16K18669). We appreciate the assistance in the field sampling by Yoshiko Otsuka and Akira Takeda.

\section{References}

Alexander, E. B. (1985) Rates of soil formation from bedrock or consolidated sediments. Phys Geogr, 6, 25-42.

Amonette, J. E. \& Zelazny, L. W., eds. (1994) Quantitative methods in soil mineralogy. Madison, Wisconsin: Soil Science Society of America.

Andrews, M. Y. et al (2008) Weathering of soil minerals by angiosperm and gymnosperm trees. Mineral Mag, 72, 1114.

Berner, R. A. (1997) The rise of plants and their effect on weathering and atmospheric $\mathrm{CO}_{2}$. Science, 276, 544-546.

Brady, N. C. \& Weil, R. R. (2007) The nature and properties of soils, 14th ed. Prentice Hall, New Jersey.

Buol, S. W. et al. (2003) Soil genesis and classification, 5th ed. Iowa State Press, Ames, Iowa.

De Master, D. J. (1981) The supply and accumulation of silica in the marine environment. Geochim. Cosmochim. Acta, 45, 1715-1732.

Fahey, T. J. et al. (2005) The biogeochemistry of carbon at Hubbard brook. Biogeochemistry, 75, 109-176.

Forest Soil Division (1976) Classification of forest soils in Japan. Bull Gov For Exp Sta, 280, 2-28 [In Japanese].

Hartmann, J. et al. (2013) Enhanced chemical weathering as a geoengineering strategy to reduce atmospheric carbon dioxide, supply nutrients, and mitigate ocean acidification. Rev Geophys, 51, 113-149.

Hirata, T. \& Muraoka, K. (1988) Effect of element cycle on stream water chemistry in forested basin. J Jpn Soc Civil Eng, 399, 131-140 [In Japanese with English summary].

Huang, L. M. et al. (2013) Weathering and soil formation rates based on geochemical mass balances in a small forested watershed under acid precipitation in subtropical China. Catena, 105, 11-20.

Japan Meteorological Agency (2014) Meteorological database. Available from: http://www.data.jma.go.jp/obd/stats/data/ en/index.html.

Komatsu, H. et al. (2011) Increasing annual runoff-broadleaf or coniferous forests? Hydrol Process, 25, 302-318.

Kondo, J. et al. (1992) Hydrological climate in Japan (3). Evapotranspiration from forest. J Jpn Soc Hydrol Water Resour, 5, 8-18 [In Japanese with English summary].

Likens, G. E. (2004) Some perspectives on long-term biogeochemical research from the Hubbard Brook ecosystem study. Ecology, 85, 2355-2362.

Lindsey, C. G. et al. (1982) A review of long-term rock durability. In Proceedings of the symposium on uranium mill tailing management. 9-10 December, Fort Collins, Colorado, 101-115.

Maesako, Y. et al. (2007) Spatial distribution of two invasive alien species, Podocarpus nagi and Sapium sebiferum, spreading in a warm-temperate evergreen forest of the Kasugayama Forest Reserve, Japan. Veg Sci (Japan), 24, 103-112.

Meybeck, M. (1987) Global chemical weathering of surficial rocks estimated from river dissolved loads. Am J Sci, 287, 401-428.

Montgomery, D. R. (2007) Soil erosion and agricultural sustainability. Proc Natl Acad Sci U.S.A., 104, 1326813272.

Moulton, K. L. et al. (2000) Solute flux and mineral mass 
balance approaches to the quantification of plant effects on silicate weathering. Am J Sci, 300, 539-570.

Nédeltcheva, T. H. et al. (2006) Influence of granite mineralogy, rainfall, vegetation and relief on stream water chemistry (Vosges Mountains, north-eastern France). Chem Geol, 231, 1-15.

Peters, N. E. et al. (2006) Water and solute mass balance of five small, relatively undisturbed watersheds in the U.S. Sci. Total Environ, 358, 221-242.

Pope, G.A. et al. (1995) A new conceptual model for understanding geographical variations in weathering. Ann Assoc Am Geogr, 85, 38-64.

Rasyidin, A. \& Wakatsuki, T. (1994) Characterization of precipitation and river water chemistry for measuring rates of weathering and soil formation in Iu river watershed, southwestern Japan. Soil Sci Plant Nutr, 40, 319-332.

Shimoda, K. et al. (1994) The regeneration of pioneer tree species under browsing pressure of Sika deer in an evergreen oak forest. Ecol Res, 9, 85-92.

Soil Survey Staff (2006) Keys to soil taxonomy, 10th ed. Natural Resources Conservation Service, USDA, Washington, DC.

Sommer, M. et al. (2006) Silicon pools and fluxes in soils and landscapes - a review. J. Plant Nutr Soil Sci, 169, 310-329.

Song, Z. et al. (2013) Plant impact on the coupled terrestrial biogeochemical cycles of silicon and carbon: Implications for biogeochemical carbon sequestration. Earth Sci Rev, 115, 319-331.

Tabata, K. et al. (2016) Environmental factors affecting growth of Cerasus jamasakura and Padus grayana in a sub-urban secondary forest. J Jpn Soc Reveg Technol, 41, 448-458 [In Japanese with English abstract].
Tabata, K. et al. (2017) Environmental preferences of major wood species in a Quercus serrata secondary forest in the suburb of Nara City. J Jpn Soc Reveg Technol, 42, 437-443 [In Japanese with English abstract].

Takeuchi, K. et al. (2002) Satoyama: the traditional rural landscape of Japan. Springer, Tokyo.

Taylor, L. L. et al. (2012) Evaluating the effects of terrestrial ecosystems, climate and carbon dioxide on weathering over geological time: a global-scale process-based approach. Philos T R Soc B, 367, 565-582.

Velbel, M. A. \& Price, J. R. (2007) Solute geochemical massbalances and mineral weathering rates in small watersheds: Methodology, recent advances, and future directions. Appl Geochem, 22, 1682-1700.

Wakatsuki, T. (1985) Soil, the sea and people: An attempt on soil genesis theory. Kagaku to Seibutsu (Chemistry and Biology), 23, 408-414 [In Japanese].

Wakatsuki, T. \& Rasyidin, A. (1992) Rates of weathering and soil formation. Geoderma, 52, 251-264.

Wakatsuki, T. et al. (1993) Multiple regression method for estimating rates of weathering and soil formation in watersheds. Soil Sci Plant Nutr, 39, 153-159.

White, A. F. \& Blum, A. E. (1995) Effects of climate on chemical weathering in watersheds. Geochim. Cosmochim. Acta, 159, 1729-1747.

Yang, J. L. et al. (2013) Estimating soil acidification rate at watershed scale based on the stoichiometric relations between silicon and base cations. Chem Geol, 337/338, 3037. 